\title{
CULTURAL DIPLOMACY \\ AS A TOOL OF UKRAINE'S FOREIGN POLICY: ACHIEVEMENTS AND CHALLENGES
}

\begin{abstract}
This article reveals the essence of cultural diplomacy as a foreign policy vector, and discusses its place among the tools of public diplomacy. The focus lies on the analysis of cultural diplomacy potential in Ukrainian foreign activities. In particular, the institutional aspects of promoting Ukrainian culture abroad are examined, and the role of foreign office and other stakeholders in these processes, including non-public subjects, is showed.
\end{abstract}

\section{Key words}

cultural diplomacy, public diplomacy, foreign policy, Ukraine

An active supplement and, to some extent, replacement of traditional diplomatic tools with new models that provide direct communication with foreign target audiences is an integral part of a foreign policy of any country that seeks to establish itself as a strong international player. An important role of this foreign policy dimension is determined primarily by the fact that today a favourable foreign public is one of the key factors that directly affects the success of the state foreign policy actions.

* Faculty of International Relations, KROK University in Kyiv, Ukraine, e-mail: vtereshchuk@ukr.net 
We can currently observe a transition from traditional diplomacy, or, as defined by R. Ammon, "old diplomacy" (Ammon, 2001), understood as the realization of foreign policy through political contacts between the governments, to the so-called "new diplomacy" that relies more on the global press and television. Due to the intervention of information technology in the process of making diplomacy, new diplomacy forms and corresponding terms have emerged, in particular - "media diplomacy", "network diplomacy", "virtual diplomacy", "real-time diplomacy" and others. Another area of diplomatic activity transformations lies in the expansion of the range of audiences targeted to established direct contacts - this has included population of other countries, NGOs, educational institutions, etc. A concept of public diplomacy has been introduced. It is understood as a dialogical communication between governments and other actors on the stage of international relations via the mass communication media and non-mediated channels of contact with the foreign countries' mass audience. The aim of public diplomacy is to create or reinforce a positive image of the country and its society, and by influencing public opinion to shape positive attitudes toward the country, and in consequence to make the achievement of international policy goals easier (Ociepka, 2008).

The role of culture in the practice of public diplomacy is very important. According to Joseph Nye, culture is a part of "soft power" resources, along with the institutions, values and policies (Nye, 2004). As far as public diplomacy can be considered as a platform for soft power implementation, culture can be examined as an integral part of public diplomacy. Moreover, promoting the culture is often the main goal of public diplomacy practices. Thus, cultural diplomacy can be distinguished as a separate, independent vector of public diplomacy.

In "Ukrainian Diplomatic Encyclopaedia" cultural diplomacy is defined as: 1) foreign cultural policy (culture policy), aimed at preserving national culture, advocating national cultural identity in international cooperation; it combines state policy on specific areas of cultural activities, culture of foreign policy activities, instrumental use of culture and cultural norms in foreign policy actions; 2) consideration of cultural factors in diplomatic activities in order to achieve inter-state agreement by overcoming cultural barriers; 3) the use of various factors, culture, art and education to protect and promote internationally the national interests (as cited in Сербіна \& Кучмій, 2011).

P. van Ham stated that cultural diplomacy remains at the core of what public diplomacy aims to achieve: to touch the general public and elites of other countries in a way that generates more understanding and support for one's own 
interests, ideas and values (Ham, 2015). However, cultural diplomacy, as well as public diplomacy as a whole, receives cautious attitude from some experts, researchers and policy makers. Quite an indicative example can be found in a "Dictionary of Diplomacy" in the first (Berridge \& James, 2001) and the second (Berridge \& James, 2003) editions, where the public diplomacy has been defined as a late-twentieth-century term for propaganda conducted by diplomats. It was only in the third edition (Berridge \& Lloyd, 2012) that this concept had been interpreted as the exploitation by professional diplomats and foreign ministries of the rich opportunities of modern communications technology to engage in a dialogue with foreign publics, albeit with a view to persuading them more effectively to their point of view.

The same situation appears to exist concerning culture diplomacy. For example, in historical encyclopaedia "Propaganda and mass persuasion" (Cull, Culbert \& Welch, 2003) the phenomenon of cultural diplomacy as filed under the title of "cultural propaganda", and described as a long-term process intended to promote a better understanding of the nation that is sponsoring the activity, which involves the dissemination of cultural products - films, magazines, radio and television programs, art exhibitions, travelling theatre groups and orchestras - as well as the promotion of language teaching and a wide range of "educational" activities, such as student-exchange schemes. These activities are designed to enhance the nation's image among the populations of other countries, with a view to creating goodwill and influencing the polices of their governments through the pressure of public opinion.

Such situation takes place, in our opinion, primarily due to several factors. Firstly, the idea of public diplomacy has largely grown out of propagandistic practices that had also focused on direct impacting target audiences, but have been more related to the use of media and influence, with focus usually lying on imposing certain thoughts, "brainwashing". In fact, the concept of public diplomacy initially was coined to refer to practices of the US information influence on the Soviet Union and the socialist countries during the Cold War. E. Gilboa has defined such activities as the "Basic Cold War model" and differentiated it from other models of public diplomacy (Gilboa, 2008).

Secondly, cultural diplomacy is often interpreted as a hidden form of cultural imperialism, and therefore, is also perceived with caution by many politicians and researchers. Somehow, the idea of cultural diplomacy has taken its place in the foreign policies of many countries. The main institutional form of exercising cultural diplomacy has traditionally been an establishment of special 
institutions such as the British Council (UK), Instituto Cervantes (Spain), the Goethe Institute (Germany), Instytut Adama Mickiewicza (Poland), Alliance Française (France), and others.

\section{Role of cultural diplomacy in Ukraine's foreign policy}

For Ukraine, the need to implement various forms of cultural diplomacy is related to several factors. Firstly, Ukraine, as well as other former Soviet and Yugoslav republics, had faced the task of forming their identity and ensuring their recognition after gaining its independence. It was for the first time that Ukraine had arose as an independent state, even if prior periods of statehood are to be taken into account. It was a central problem for Ukraine to separate itself from Russia, often identified with the former USSR whole by ordinary public opinion worldwide. Understanding the importance of this problem occurred at the state level, for example, the book by then-President of Ukraine Leonid Kuchma, published in 2003, was eloquently titled "Ukraine is not Russia". The author shared his views on Ukrainian past, the events of $20^{\text {th }}$ century and the latest years with a consideration given to whether Ukraine could have been considered a former Russian colony and review of the common historical and cultural heritage problems and mutual "debts" (Кучма, 2003). Culture factor should play a significant role in order for a distinctive Ukrainian culture, being duly presented abroad, to become the foundation for the formation of foreign audiences' background knowledge about Ukraine and for the establishment of the priming effect.

Secondly, implementation of cultural diplomacy strategy in conjunction with other communicative instruments (media diplomacy, nation branding, etc.) could provide certain support of Ukrainian foreign policy actions among foreign audiences, which is particularly relevant in the current context of military aggression from Russia. Ukrainian researcher T. Hrachevska noted that the inadmissibility of ignoring the development of cultural diplomacy and lack of support to its subjects has been demonstrated in Ukraine for the past two years. Due to lack of information about Ukraine in other states, and considering the conditions of armed aggression, Ukrainian diplomatic missions and cultural institutions should create mechanisms not only to promote national cultural product, but also to provide truthful information about the events on the territory of Ukraine. This is not simply a matter of creating a positive international image, but a matter of homeland security (Грачевська, 2016). 
Officially, the need to implement the cultural component of Ukraine's foreign policy had been recognized in 2006. The then-President of Ukraine had approved by Decree 142/2006 the "Regulation on Cultural-informational centre in the structure of foreign diplomatic mission of Ukraine". The following main objectives of these centres were proclaimed: to promote international cooperation of Ukraine in the fields of culture, education, science and technology, tourism, physical culture and sports in a host state; to disseminate information about Ukraine in a host state; to familiarize citizens of a host country with the history and culture of Ukraine, to promote Ukrainian language in the territory of that state; to liaise with Ukrainians abroad, contributing to their cultural, linguistic, informational and other needs; to disseminate information about tourism opportunities and attractiveness of Ukraine, to promote cooperation with a host state in tourism (Положення про культурно-інформаційний центр у складі закордонної дипломатичної установи України, 2006). It should be noted that such an operation of the centres, according to the above-mentioned Regulation, should be organized, in addition to the Foreign Ministry, by the Ministry of Culture and Tourism of Ukraine, the Ministry of Education and Science of Ukraine, the Ministry for Family, Youth and Sports of Ukraine, and the State Committee for Television and Radio Broadcasting of Ukraine.

Today, according to the "List of foreign diplomatic institutions of Ukraine, which form in their structure a Cultural-informational centre", approved in 2006 and amended in 2008 and 2012, there are 31 operating cultural-informational centres, including 27 at the diplomatic missions of Ukraine and 4 at the Consulates General of Ukraine. It should be noted that there are 16 of such centres in the diplomatic missions of Ukraine in the EU-member states (see: Перелік закордонних дипломатичних установ України, у складі яких утворюються культурно-інформаційні центри, 2006).

Meanwhile, expert estimates indicate that the activities of these centres are inefficient. As an example, the National Institute for Strategic Studies had prepared an analytical note "Optimization of strengthening Ukraine's cultural presence in Europe" in 2014, stating that the activities of the centres were limited to protocol events or advocacy activities (on the Day of Unification and Freedom of Ukraine, International Mother Language Day, Shevchenko days, etc.), annual celebrations of anniversaries, and commemoration of famous Ukrainians, whilst examples of activities that provided long-term relationships and cooperation were rare. Summing up the work of cultural missions of Ukraine abroad during the years 2011-2013, the document outlined the following trends in their activities: a small number of staff and a lack of specialists in cultural management, 
which had certainly complicated the presentation of national culture and its promotion on the international arena; dissemination of information about Ukraine without the prospects of cultural cooperation had prevailed among the activities undertaken by the centres in European countries; disseminated information about Ukraine primarily related to the past of the Ukrainian people and their traditional culture, and an actual development of culture and civil society were overlooked; in most cases, diplomatic agreements purely contained formal measures such as exchange of delegations, unnecessarily large part of which were diplomatic services officials or ministries; with overall only a simulacrum of real work (Національний інститут стратегічних досліджень, 2014).

In recent years, there has been a practice in the field of cultural diplomacy to employ not career diplomats, but cultural and public sector activists. Thus, Ukrainian writer, singer, journalist, TV presenter Irena Karpa was appointed as the first Culture secretary of the Embassy of Ukraine in France in 2015 (Укрінформ, 2015, October 12), and Oleksandra Saenko, public figure, member of the NGO "Democratic Ukraine" (its representatives actively participated in actions in support of Ukraine in Austria, in particular, in supplying local media with perspective on events in Crimea and Eastern Ukraine, confronting Russian propaganda) was appointed as a cultural attaché at the Embassy of Ukraine in Austria. (Free Voice Information Analysis Center, 2016, January 6).

It was only in the recent years that the foreign ministry of Ukraine has increased interest to the public and, in particular, cultural diplomacy. Thus, on June 2, 2015, at the Diplomatic Academy of Ukraine, the First Cultural Diplomacy Forum of Ukraine of Ukraine was held. Foreign Ministry initiated the holding of such event with an aim to create a platform for interaction between all stakeholders to promote Ukrainian cultural product in the world and Ukraine's integration into the global cultural space. During the Forum, Foreign Minister of Ukraine Pavlo Klimkin had announced a creation of a special department in Foreign Ministry directed at dealing exclusively with the matters of cultural diplomacy. "For the first time cultural diplomacy appears in the structure of the Foreign Ministry as a holistic concept. This department will be integrated into the operations of the Foreign Ministry in the sphere of Ukrainian international communications. This synergy should yield results. Cultural projects will be an integral part of our efforts to explain to the world what Ukraine is and what it wants. Art communicates not just images, but meanings" (МЗС України, 2015, June 2).

This idea has been embodied in the establishment of the Office of Public Diplomacy of the Ministry of Foreign Affairs of Ukraine on December 22, 2015. 
The main tasks of the Office have been defined as following: a development of relations with the public, an establishment of civil society groups and the media in other countries and in Ukraine; a realization of Ukrainian image, culture and information projects abroad; a coordination of activities of other executive bodies in these areas (МЗС України, 2015, December 22). As can be seen, the newly formed division has a wide range of activities in which cultural diplomacy has become only one of the directions. Such approach can be justified in the view of the fact that the absence of full implementation of the strategy of public diplomacy paying attention to only one of its vectors is not likely to have the desired effect. In addition, as noted above, the traditional practices of cultural diplomacy include the creation of special separate institutions.

However, cultural diplomacy as an independent direction has not disappeared from the agenda of Ukrainian foreign policy. Thus, during the Second Cultural Diplomacy Forum of Ukraine, held on 27 April 2016, the participants, including, the Ukrainian and American diplomats, experts of Kennan Institute Kyiv Office and the NGO "Global Ukrainians", have developed a number of recommendations on promoting Ukrainian cultural diplomacy to a new level of efficiency and strategic planning. These are as follows. There is a need to develop a coherent strategy for Ukrainian cultural diplomacy. An implementation of cultural diplomacy is impossible without proper communication with the public and private sectors. Cultural diplomacy requires investment in human resources, training, seminars, online training, etc. Projects of cultural diplomacy should have a clear and concentrate message. Ukrainian cultural diplomacy should multiply "capital" of foreign audiences' sympathy. Diaspora cultural diplomacy should be actively encouraged by the state. Establishment of cooperation between local business and cultural environment will contribute to the successful export of Ukrainian products abroad (МЗС України, 2016, April 28).

We should also note the initiative of the Ministry of Foreign Affairs of Ukraine to support cultural projects for foreign audiences. In December 2015, the Ministry had announced a possibility of Internet applications to support such projects. A selection of projects will take place on a regular basis by an expert platform of MFA on cultural diplomacy issues. It was also noted that financial support could be quite limited; the focus is on informational support, assistance in finding partners, recommendations, logistics and so on (Культурна дипломатія України від МЗС / Ukraine's Cultural Diplomacy by MFA, 2015, December 9). 


\section{Cultural diplomacy initiatives beyond the Foreign Ministry of Ukraine}

As noted above, it is a common practice in many countries to create special institutions designed to promote their culture abroad.

A State Agency of Culture Promotion of Ukraine was established in 2009 in accordance with the Decree of Ministry of Culture Tourism of Ukraine, January 16, 2009 No 10/0/19.16 "On renaming Ukrainian Cultural-educational centre "Druzhba". The Centre, in turn, had been created under the Decree of the Ministry of Culture of Ukraine, January 25, 1993 No 7 "On reorganization of Cultural-educational centre "Druzhba". During the years of operation there were around 2,000 projects of international, national and local trends held, such as art festivals, open-air exhibitions contests, days of culture of foreign countries in Ukraine and the Days of Culture of Ukraine in foreign states, presidential meetings, intergovernmental commission, and many others. State Agency of Culture Promotion of Ukraine cooperates with national cultural societies, NGOs, organizations dealing with persons with disabilities, creative teams, and volunteer organizations. One of the activities of the Agency is to coordinate international cultural relations (Державна агенція промоції культури України, 2014, December 26).

However, we cannot talk about a significant role of this Agency as an actor of Ukrainian Cultural Diplomacy. Moreover, according to the official internet portal "KYIVAUDYT", the State Agency of Culture Promotion of Ukraine is subordinate to the Department of Culture of the Kyiv City Council (Kyiv City State Administration), which implicates its funding to be transferred from the state budget to the local budget of Куіv (КИЇВАУДИТ). This is likely to downgrade the status of the organization. At present, the Agency does not even have its own website.

The idea of establishing a new institution for the promotion of Ukrainian culture abroad had been announced on March 31, 2015 by the Ministry of Culture of Ukraine. A Draft Concept of Ukrainian Taras Shevchenko Institute, developed the Ukrainian Centre for Cultural Studies, had been opened to the public discussion. On April 28 of the same year, the Ministry of Culture of Ukraine had held a round table of cultural centres of European countries (Great Britain, Poland and the Czech Republic), who had offered their experience and shared the features of their institutions. Government officials and NGOs were also present. Proposals submitted during the public discussion, and suggestions of participants of the round table had been taken into account during the 
preparation of the Concept public presentation. The related event, held on June 11, 2015, had been attended by European diplomats, leaders of the European programs and cultural centres (including the representatives of the cultural centres of the EU, the US and Canada in Ukraine, the head of the EU's Eastern Partnership Culture Programme), Ukrainian experts activists, media (Міністерство культури України, 2015, March 31; Урядовий портал, 2015, April 28; Міністерство культури України, 2015a, June 11).

In the presented Concept of Ukrainian Institute (Institute of Taras Shevchenko) the following principal objectives of its activities were identified: to disseminate, especially via the Internet space, information about cultural life of Ukraine, its cultural heritage and history around the world; to promote close links between cultural, artistic and intellectual circles of Ukraine and other nations, and to create a greater awareness of Ukrainian cultural heritage and modern culture in the world community; to ensure the presence of Ukrainian culture in the world cultural and informational space, to promote national cultural product on the world market; to assist in providing cultural and educational needs of the Ukrainian community in various countries, and in popularization and learning Ukrainian language; to create a positive image of Ukraine in the world by means of culture and international cultural cooperation (Міністерство культури України, 2015b, June 11). This list of goals appears to reflect traditional European vision of cultural diplomacy role and tasks.

It is envisaged that the Ukrainian Institute will create a network structure (consisting of a central agency in Ukraine and a network of cultural centres abroad), ensure a non-governmental status, build a contractual relationship with the Ministry of Culture and the Ministry of Foreign Affairs, and implement the idea of public-private partnership (via co-opting representatives of cultural and artistic community, government, business for involving formation of strategy, planning and implementing tasks of the Institute). We should note that the Concept of the Ukrainian Institute (Institute of Taras Shevchenko) proclaims countries of Central and Eastern Europe, the EU and G7, as well as countries where there are substantial Ukrainian communities, among the priorities in the formation of a network of foreign centres.

In addition, a round table "Cultural Diplomacy: interaction of public and private institutions", had been initiated by the Foreign Affairs Committee of the Parliament of Ukraine to be held on December 9, 2015. Deputy Culture Minister for European Integration Andriy Vitrenko had presented a draft law "On Ukrainian Institute" created by the Ministry of Culture of Ukraine. A special interdepartmental working group had been created, and, on the basis of its 
activities modified, a bill had been prepared. This was presented to the Foreign Affairs Committee of Verkhovna Rada of Ukraine in April 2016 (Міністерство культури України, 2015, December 9; Міністерство культури України, 2016a, April 13).

It is worth noting that this draft bill has significant characteristics of the Ukrainian Institute in comparison with the above-mentioned Concept. In particular, the draft suggests that the legal status of the Ukrainian Institute should be defined as a state institution, which relates to the jurisdiction of the Cabinet of Ministers of Ukraine; and that the objectives of the Institute are the following: formation of a positive image of Ukraine in the world; promotion of a national cultural product; popularization of the modern Ukrainian culture and Ukrainian scientific and cultural life; dissemination of the knowledge about cultural heritage and tourism potential; strengthening international cooperation and cultural exchanges in the fields of culture and arts, cultural heritage, language policy, cinematography, education, scientific and technical activities, foreign relations of Ukraine, youth policy, tourism and resorts policy (Міністерство культури України, 2016b, April 13). It is likely that the specified list of goals is much wider than envisaged in the Concept.

Long-time inertia of Ukraine in the matters of cultural diplomacy has led to some (albeit rare) private initiatives in this area. The most striking example is Ukrainian Institute in Sweden, which was established in August 24, 2014 as a private initiative of a Ukrainian pianist Natalia Pasichnik and a soloist of the Warsaw opera Olha Pasichnik. Its mission was declared to "put Ukraine on the cultural map of Sweden through cultural, educational and charitable activities", and its purpose was "to open up cultural Ukraine to the world" (Ukrainian Institute of Sweden).

It should be noted that this initiative was supported by the Embassy of Ukraine in Sweden. The then-Charge d'Affaires of Ukraine in Sweden Ihor Tseluyko had commented that "Unfortunately, the state does not have enough funds to establish institutes of Ukrainian culture in Europe. However, the embassy supports the initiatives of individuals in this area. This time the event organized by Natalia Pasichnyk is supported by the diplomatic corps. Ukraine allocates money to some cultural programs, so we try to support the Institute established by Natalia Pasichnyk via public funds and the relations that the Embassy of Ukraine has developed” (День, 2014, August 27).

In addition, the current Minister of Culture of Ukraine Yevhen Nyschuk had declared his willingness to support the Ukrainian Institute in Sweden: "Such initiatives should be supported and elaborated on by further joint efforts for 
all the best ideas to be embodied in life. Moreover, support of such institutions should be done not by the means of symbolic gestures, but by the discussions of the specific tasks and propositions of solutions. We, as the Ministry of Culture are open to build effective mechanisms of cooperation, including fundraising, with the Foreign Ministry and other state institutions. This is especially important now, when the degree of interest in Ukraine is great, and the work of these centres is an important step in the cultural diplomacy" (Міністерство культури України, 2016, Мау 13).

Co-opting of Ukrainian Institute in Sweden to Ukraine's foreign policy initiatives was formalised on the July 17, 2015 when the Ministry of Culture of Ukraine, the Embassy of Ukraine in the Kingdom of Sweden and the Ukrainian Institute in Sweden had signed the tripartite memorandum, declaring the intention to deepen Ukrainian-Swedish culture cooperation through common goals, and to carry out information and educational work for promoting Ukrainian culture and art in Sweden. Such cooperation strives to aid forming of Ukraine's positive image and to stimulate interest in its national culture (Західна інформаційна корпорація, 2015, July 17).

\section{Conclusion}

The role of cultural diplomacy as an instrument of Ukrainian foreign policy can be summarised as follows.

1) Cultural diplomacy has been virtually absent in the foreign policy of Ukraine for a long time. A creation of cultural-informational centres as part of foreign diplomatic missions of Ukraine since 2006, has been only a formal attempt to introduce a cultural dimension to the Ukrainian diplomatic practice. The operation of these centres has proved to be inadequate both in material and in staff matters, and has failed to formulate the vision of the Ukrainian culture role among foreign policy imperatives. As a result, only a few centres have shown an active effort to promote Ukrainian culture in the host countries, and this was primarily at the merit of their employees.

2) The reconsideration of the role of cultural diplomacy and its confident ingression into Ukrainian foreign policy took place only following the "Revolution of dignity". In particular, the discussions have involved the public and the experts, the Office of Public Diplomacy in the Ministry of Foreign Affairs of Ukraine, and have crystallized the idea of creating a model of European countries special institutions directed at the promotion of 
Ukrainian culture abroad to be put into practice by the culture and civil society community co-opting persons to cultural-informational centres at Ukrainian diplomatic missions.

3) A lack of a comprehensive government attention to cultural diplomacy has led to an emergence of private initiatives, the most striking of which is the Ukrainian Institute in Sweden. On one hand, it demonstrates a high potential of non-state stakeholders in the promotion of Ukrainian culture in foreign countries, on the other, it highlights a lack of adequate state participation in these processes even more clearly.

4) It is too early today to consider the impact of institutional state initiatives on the cultural diplomacy. However, there appears to be a lack of a regulatory support of cultural vector of Ukrainian foreign policy, in particular, there is an absence of a systematic program document that could define the goals and objectives of Ukrainian cultural diplomacy and the timing of their implementation, and there is a limitation of the necessary resources, etc. In addition, parallel implementation of the initiatives of the Ministry of Foreign Affairs and of Ministry of Culture of Ukraine can prove coordinating efforts and identifying areas of responsibility problematic.

\section{REFERENCES}

Ammon, R. J. (2001). Global Television and the Shaping of World Politics: Telediplomacy and Foreign Policy. Jefferson, NC: McFarland.

Berridge, G. R., James, A. (2001). A Dictionary of Diplomacy. Basingstoke: Palgrave Macmillan.

Berridge, G. R., James, A. (2003). A Dictionary of Diplomacy (2nd ed.). Basingstoke: Palgrave Macmillan.

Berridge, G. R., Lloyd, L. (2012). The Palgrave Macmillan Dictionary of Diplomacy (3rd ed.). Basingstoke: Palgrave Macmillan.

Cull, N.J., Culbert, D., Welch, D. (Eds.). (2003). Propaganda and Mass Persuasion: a historical encyclopedia, 1500 to the present. Santa Barbara, CA: ABC-CLIO.

Free Voice Information Analysis Center (2016). Олександра Саєнко: «Австрійці дуже чутливі до мистецтва та культури, тому культурна дипломатія у Австрії точно працює». Retrieved from http://iac.org.ua/oleksandra-sayenko-avstriytsi-duzhechutlivi-do-mistetstva-ta-kulturi-tomu-kulturna-diplomatiya-u-avstriyi-tochnopratsyuye/

Gilboa, E. (2008). Searching for a Theory of Public Diplomacy. The ANNALS of the American Academy of Political and Social Science, 616, pp. 55-77. 
Ham, P. van (2010). Social Power in International Politics. Abingdon, Oxon: Routledge. Nye, J.S. (2004). Soft Power: the Means to Success in World Politics. New York: PublicAffairs.

Ociepka, B. (2008). Public Diplomacy. In W. Donsbach (ed.), The International Encyclopedia of Communication (pp. 3956-3960). Malden, MA: Blackwell Publishing.

Ukrainian Institute of Sweden (n.a.). Retrieved from http://ukrainskainstitutet.se/en/ our-mission/

Грачевська, Т. О. (2016). Діяльність культурно-інформаційних центрів як компонента культурної дипломатії. Грані, 2(130), рp. 22-26.

День (2014). У Швеції розпочав роботу Український Інститут. Retrieved from http:// day.kyiv.ua/uk/article/kultura/u-shveciyi-rozpochav-robotu-ukrayinskiy-institut Державна агенція промоції культури України (2014). Шановні колеги, друзі, однодумці!. Retrieved from https://www.facebook.com/permalink.php?story_fbid=1027 255630634389\&id=904036179623002

Західна інформаційна корпорація (2015). У Швеції популяризовуватимуть українську культуру. Retrieved from http://zik.ua/news/2015/07/17/u_shvetsii_populyaryzovuvatymut_ukrainsku_kulturu_608313

КИЇВАУДИТ (n.а.). Державна установа 'Державна агенція промоції культури України". Retrieved from http://kyivaudit.gov.ua/vr/ka/company.nsf/(pdpr)/8BE96 272D11614CFC2257ED50047FF40?OpenDocument

Культурна дипломатія України від M3C / Ukraine’s Cultural Diplomacy by MFA (2015).Запит напідтримкуМЗСуреалізаціїкультурногопроекту. Retrieved from https://www.facebook.com/CulturalDiplomacyUkraine/posts/1056919127662862 Кучма, Л. (2003). Украина - не Россия. Москва: Время.

МЗС України (2015). В МЗС відбувся Перший форум культурної дипломатії України. Retrieved from http://mfa.gov.ua/ua/press-center/news/37021-v-mzs-vidbuvsyapershij-forum-kulyturnoji-diplomatiji-ukrajini

МЗС України (2015). В МЗС створено новий напрям роботи - публічна дипломатія. Retrieved from http://mfa.gov.ua/ua/press-center/news/43433-v-mzs-stvorenonovij-napryam-robotipublichna-diplomatija

МЗС України (2016). 27 квітня в Дипломатичній академії при МЗС України відбувся Другий форум культурної дипломатії України. Retrieved from http://mfa. gov.ua/ua/press-center/news/47000-27-kvitnya-v-diplomatichnij-akademiji-primzs-ukrajini-vidbuvsya-drugij-forum-kulyturnoji-diplomatiji-ukrajini

Міністерство культури України (2015). Роз'яснення Міністерства культури щодо підготовки концепції Українського інституту (Інституту Тараса Шевченка). Retrieved from http://mincult.kmu.gov.ua/control/publish/article?art_id=244963714

Міністерство культури України (2015a). Рішення про створення Українського інституту буде ухвалено до кінця року - В’ячеслав Кириленко. Retrieved from http://mincult.kmu.gov.ua/control/publish/article?art_id=244963812 
Міністерство культури України (2015b). Концепція створення Українського інституту (Інституту Тараса Шевченка). Retrieved from http://195.78.68.75/mcu/ document/244963749/Institut_Shevchenka.doc

Міністерство культури України (2015). Мінкультури пропонує разом з депутатами і громадськістю удосконалити проект законупро Український інститут. Retrieved from http://mincult.kmu.gov.ua/control/publish/article?art_id=245083513

Міністерство культури України (2016а). Проект закону "Про Український інститут". Retrieved from http://mincult.kmu.gov.ua/control/publish/article?art_ id $=245084295$

Міністерство культури України (2016b). Проект Закону України «Про Український Інститут». Retrieved from http://mincult.kmu.gov.ua/document/245084320/ Proekt_zakonu_pro_Ukrainskiy_Institut.doc

Міністерство культури України (2016). «Підтримка роботи Українського інституту у Швеції - важливий крок у культурній дипломатії - Євген Нищук. Retrieved from http://mincult.kmu.gov.ua/control/uk/publish/article?art_id=245095538

Національний інститут стратегічних досліджень (2014). Оптимізація посилення культурної присутності України в Європі. Аналітична записка. Retrieved from http://www.niss.gov.ua/articles/1522/

Перелік закордонних дипломатичних установ України, у складі яких утворюються культурно-інформаційні центри. Затверджений розпорядженням Кабінету Міністрів України від 19 квітня 2006 р. № 213-p. Retrieved from http:// zakon4.rada.gov.ua/laws/show/213-2006-p

Положення про культурно-інформаційний центр у складі закордонної дипломатичної установи України. Затверджене Указом Президента України від 20 лютого 2006 року № 142/2006. Retrieved from http://zakon4.rada.gov.ua/laws/ show/142/2006

Сербіна, Н. Ф., \& Кучмій, О.П. (2011). Культурна дипломатія як інструмент зовнішньої політики сучасної європейської держави. Актуальні проблеми міжнародних відносин: 3бірник наукових пращ, , 100(1), pp. 122-131.

Укрінформ (2015). Український культурний центр у Парижі очолить Ірена Карпа. Retrieved from http://www.ukrinform.ua/rubric-culture/1896784-ukrajinskiykulturniy-tsentr-u-pariji-ocholit-irena-karpa.html

Урядовий портал (2015). У Міністерстві культури відбулося обговорення проекту концепції Українського інституту Тараса Шевченка. Retrieved from http://www. kmu.gov.ua/control/publish/article?art_id=248126682 